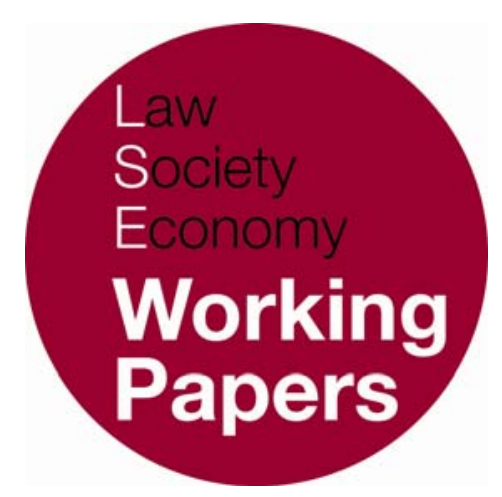

\title{
Breaking Promises To Keep Them: Immigration and the Boundaries of Distributive Justice
}

\author{
Hans Lindahl
}

LSE Law, Society and Economy Working Papers 3/2007

London School of Economics and Political Science

Law Department

This paper can be downloaded without charge from LSE Law, Society and Economy

Working Papers at: www.lse.ac.uk/collections/law/wps/wps.htm and the Social Science Research Network electronic library at: http://ssrn.com/abstract=999945

(C) Hans Lindahl. Users may download and/or print one copy to facilitate their private study or for non-commercial research. Users may not engage in further distribution of this material or use it for any profit-making activities or any other form of commercial gain. 


\title{
Breaking Promises To Keep Them:
}

\section{Immigration and the Boundaries of Distributive Justice}

\author{
Hans Lindahl*
}

\begin{abstract}
Theories of distributive justice have great difficulties in conceptualizing immigration as a political rather than a moral problem. Exploring the reasons for this reductive move, and explaining why it is self-defeating, this paper argues that immigration poses a thoroughly political problem because spatial boundaries are posited from the first-person plural perspective of a 'we.' Yet the politics of boundaries deployed in immigration policy are also necessarily problematic: while polities claim a right to include and exclude aliens because a territory is held to be the own place of their citizens, an act of inclusion and exclusion gives rise to a 'we.' This circularity disrupts - without effacing-the inside/outside and right/fact distinctions that underpin the right to closure polities claim for themselves. The stake of this disruption is temporal no less than spatial: as polities close themselves into a legal space through a mutual promise to which there is no direct access, distributive justice requires that authorities decide what promises had been made in the light of boundary crossings that determine what promises can be kept.
\end{abstract}

Although immigration is widely recognized as raising urgent distributive issues, it has proven difficult for theories of distributive justice to conceptualize immigration in a way that does not ultimately trade in politics for morality. The temptation to move from politics to morality is great: to the extent that political boundaries entail an asymmetric relation between citizens and aliens, such that those inside decide between themselves who may or may not enter the polity from outside, morality suggests a form of reciprocity between individuals that is in principle unlimited, thereby releasing a theory of distributive justice from the constraints introduced by political asymmetry. While attractive at first sight, this move is self-defeating. For distributive justice requires that a political community

* Associate Professor of Legal Philosophy, Department of Philosophy, Tilburg University, The Netherlands. This paper was funded by a research grant provided by the Netherlands Organisation for Scientific Research (NWO). A preliminary version of this paper was presented at the Law Department of the London School of Economics. I greatly appreciate the in-depth comments to this preliminary version by Dora Kostakopoulou, Martin Loughlin, Damian Chalmers, and Emmanuel Melissaris. 
enact a legal order that identifies, first, what rights accrue to whom, and, second, officials that, in case of conflict, can authoritatively distribute rights among contending parties. To abandon the bounded reciprocity of political community in favor of the unbounded reciprocity of morality is to forfeit a constitutive condition of distributive justice. But simply reaffirming the asymmetry of the positions inside and outside a polity seems to collapse distributive justice into the sheer positivity of positive law, such that immigration ceases to be a problem about distributive justice.

This paper suggests a way out of this conceptual impasse. It argues that immigration is a political problem from beginning to end because the boundaries of a community are posited from the first-person plural perspective of a 'we' as a unity in distributive action. Justice is spatially circumscribed because every distributive act posits, explicitly or implicitly, a boundary separating inside from outside, and does so from within what is deemed to be a collective's own space. The paper further argues that immigration poses a political problem because the conditions governing the self-closure of a polity disrupt-without effacing - the opposition between an inside and an outside. Although polities claim a right to include and exclude aliens because a territory is the own place of their citizens, an act of inclusion and exclusion gives rise, in the first place, to the distinction between citizen and alien. This paper explores how this circularity renders de jure boundaries vulnerable to contestation by 'de facto immigrants,' and how it also conditions the possibility of acts of distributive justice in the face of such contestation. Ultimately, it will be argued, the spatiality of distributive justice is rooted in time, in the paradoxical temporality of political judgment: as the selfclosure of a polity arises through a mutual promise to which there is no direct access, immigration policy has to decide what promises had been made in the light of boundary crossings that determine what promises can be kept.

\section{II}

It is important to note, at the outset, that my aim in this section is not to offer a comprehensive survey — let alone detailed analysis — of the large and ever growing literature on the relation between migration and distributive justice. ${ }^{1}$ My initial, more limited aim is to understand why theories of distributive justice tend to move from a political to a moral treatment of immigration, and why we should resist this move. This is by no means to deny that immigration raises urgent moral issues. Instead, my claim is that abandoning a political approach to immigration entails forfeiting a condition of possibility of distributive justice. To make as strong a case as possible for this view, it is instructive to focus on two very different, even

${ }^{1}$ See V. Bader's recent article, 'The Ethics of Immigration' (2005) 12 Constellations 331, for a systematic survey of this literature. 
conflicting approaches that, on the face of it, develop explicitly political readings of immigration and distributive justice.

The first of these analyses is Michael Walzer's discussion of membership and immigration in his well-known book, Spheres of Justice. As Walzer points out, membership has become an issue of paramount importance for polities confronted with significant numbers of immigrants. Consequently, a theory of distributive justice must begin by scrutinizing the acts by which a polity admits or turns away aliens, not only because such acts precede the distributive question concerning the conditions for naturalization, but also because they determine all further distributive decisions in the polity. Walzer summarizes his position as follows: 'The idea of distributive justice presupposes a bounded world within which distributions take place: a group of people committed to dividing, exchanging, and sharing social goods, first among themselves. That world ... is the political community.'2 To be sure, he quickly adds that a political community is by no means a self-contained distributive unit; distribution also takes place across the boundaries that separate political communities. But, he argues, distributive decisions about cross-boundary movements, in particular about the entry of persons to a polity, are collective decisions taken from within. On this view, a right to inclusion and exclusion is ingredient to the very concept of distributive justice. This means that, subject to certain limitations, it is up to a political community to determine who and what may enter the community. As Walzer candidly puts it, 'no one on the outside has a right to be inside'. ${ }^{3}$

Walzer's defense of bounded justice is a political argument, namely an argument about collective self-determination. Indeed, 'admission and exclusion are at the core of communal independence... without them, there could not be communities of character, historically stable, ongoing associations of men and women with some special commitment to one another and some special sense of their common life'. ${ }^{4}$ Three aspects of this argument deserve mention here. First, Walzer stresses that the right to inclusion and exclusion is a collective right, a right that accrues to the members of a community acting as a whole. Second, this right is part and parcel of collective freedom because it safeguards the polity as a group of individuals committed to upholding and promoting shared values. These values lend a community its distinctiveness or 'character.' In other words, Walzer maintains that the political reciprocity of self-determination is perforce limited, for it presupposes a shared commitment to a determinate conception of the good. Accordingly, the statuses of citizen and alien are not simply interchangeable; the mutual commitment of citizens implies a mutual preference vis-à-vis aliens. Obviously, this preference is political, not personal. Third, the argument for bounded justice and a concomitant collective right to closure ultimately rests on

\footnotetext{
${ }^{2}$ M. Walzer, Spheres of Justice: A Defense of Pluralism and Equality (New York: Basic Books, 1983) 31.

3 ibid, 41 .

4 ibid, 62.
} 
collective identity: "the link between people and land is a crucial feature of national identity'. 5

While Walzer presents a political argument in defense of the boundedness of distributive justice, his approach also requires treating immigration as a moral problem. Indeed, once it is taken for granted that communities enjoy a right to closure, the question inevitably arises whether there are limitations to this right. Walzer readily grants such limitations, most notably the 'principle of mutual aid'. ${ }^{6}$ But it is also clear from his account that this principle is moral in character, rather than political. It speaks to a form of cross-boundary reciprocity between individuals as moral beings that suspends the constraints of intramural political reciprocity between citizens.

While there are certainly good reasons for giving serious attention to the principle of mutual aid, the prior question is whether Walzer's political argument in favor of the boundedness of distributive justice is sufficiently political. Indeed, does he go far enough when insisting that first admission is the initial-and essential-distributive act? Consider the following passage: 'We assume an established group and a fixed population,' Walzer notes, 'and so we miss the first and most important distributive question: How is that group constituted?' Having posed this question, one would expect him to bring the primordial distributive act - the spatial closure that constitutes a political community by separating citizen from alien-within the compass of a theory of distributive justice. For, surely, a right to inclusion and exclusion is contingent, from the point of view of a theory of distributive justice, on the conditions governing the primordial closure. Remarkably, however, Walzer arrests his questioning precisely at this point. Having raised the question, 'How is that group constituted?', he immediately qualifies its scope: 'I don't mean, How was it constituted? I am concerned here not with the historical origins of the different groups, but with the decisions they make in the present about their present and future populations'. ${ }^{8}$ Despite having insisted that the primary distributive act concerns membership, Walzer removes from a theory of distributive justice the very closure that, dividing space into an inside and an outside, gives rise to citizens and aliens in the first place. This closure is a political, not a pre-political act, as Walzer seems to take for granted. As we shall see, immigration is a thoroughly political problem because the distinction between inside and outside is not only the presupposition of acts of distributive justice but also what boundary crossings continuously call into question as a politico-legal distinction. 
Jürgen Habermas is certainly not the only liberal thinker to challenge Walzer's thesis that distributive justice is bounded. But his position is particularly apposite to our analysis because he acknowledges and attempts to overcome a political difficulty emerging from the fundamental premise shared by a wide range of defenses of a right to migration. In an important article on this topic, Joseph Carens articulates the common premise underpinning Nozick, Rawls and utilitarianism. He argues that these three strands of moral thinking endorse a right to migration because all three share the conviction that moral personhood, rather than citizenship, is fundamental to a theory of distributive justice. 'Our commitment to civic equality is derived from our convictions about moral equality, not vice versa. ${ }^{9}$ In the context of this paper it is instructive to see how Habermas attempts to reconcile this conviction with a politico-legal approach to distributive justice. Although I cannot argue this point fully for reasons of space, the vicissitudes of Habermas' approach to migration are exemplary for the difficulties encountered by all normative approaches that would derive political equality from moral equality.

Habermas' response to Walzer's model of bounded justice begins by pointing to an ambiguity in the concept of nation. On the one hand, a 'nation' can be construed as a community of descent with a shared historical destiny, that is, a group of individuals who are integrated geographically, and who share common traditions, language, customs, and the like. The French revolution bears witness to the emergence of a second concept of nation, namely as the holder of sovereignty. Whereas nationalism views citizenship in terms of membership in a cultural and ethnic community, republicanism does so solely in terms of participation in a political community. Although historically intertwined, these two understandings of nation are conceptually distinct. Their political dissociation is all the more necessary because the contemporary experience of social pluralism deprives a cultural interpretation of collective self-legislation of an empirical and normative foundation. Only the republican conception thereof yields a solid normative basis for addressing the issues of distributive justice arising in the context of immigration policy. As Habermas sees it, the political and social boundaries of a polity do not exhaust the responsibilities accruing to its citizens in the light of immigration. 'The moral point of view obligates us to assess this problem impartially, and thus not just from the one-sided perspective of an inhabitant of an affluent region but also from the perspective of immigrants who are seeking their well-being there.'10 Accordingly, the distributive question, 'Who has the right to immigrate?', must be settled by identifying the apposite criteria 'from the

9 J. Carens, 'Aliens and Citizens: The Case for Open Borders' (1987) 49 The Review of Politics 251, 256-257. 10 J. Habermas, 'Citizenship and National Identity' in J. Habermas, Between Facts and Norms (Cambridge, Mass.: The MIT Press, trans. William Rehg, 1998) 491, 511. 
perspective of all parties involved.'11 Given this injunction, 'national governments also have to see to it that citizens fulfill their positive duties toward nonmembers, such as asylum seekers. ${ }^{12}$

But what is the status of these 'positive duties'? Are they moral? Or are they legal? This question exposes two major difficulties in Habermas' initial attempt to provide a normative grounding of immigration policy by deriving political equality from moral equality. The first concerns the hiatus separating moral from political reciprocity. Whereas morality is driven by a reciprocity that is in principle unlimited in scope, politics lives from the limitation of 'all interested parties.' Habermas obliquely recognizes this, when signaling that, in processes of democratic self-legislation, 'citizens want to regulate their living together according to principles that are in the equal interest of each and thus can meet with the justified assent of all'.13 Thus, citizens, as political equals, decide what counts as their shared interest. Although they can take into account the interest of aliens, and even may be prepared to accept a right to immigration as the default setting of the collective's immigration policy, this inclusiveness presupposes and confirms the asymmetry of political reciprocity. Secondly, abandoning reciprocity between citizens in favor of reciprocity between moral persons entails relinquishing a necessary condition of distributive justice: a legal order that identifies, first, what rights and goods can be attributed to whom, and, second, the officials that, in the face of dispute, can authoritatively establish what should be allotted to whom.

In a later essay Habermas faces up squarely to these difficulties. Rejecting the distinction between human-i.e. moral - rights and fundamental-i.e. legalrights, he boldly proclaims that ' $[\mathrm{h}]$ uman rights are juridical by their very nature. What lends them the appearance of moral rights is ... their mode of validity, which points beyond the legal orders of nation-states.' ${ }^{14}$ The foundation of a world state, ${ }^{15}$ would secure their status as enforceable, subjective rights, and would assure all individuals of membership as free and equal citizens. Crucially, it would address the problem of political asymmetry between citizens and aliens, for a world state 'establishes for the first time a symmetry between the juridification of social and political relations both within and beyond the state's borders'. ${ }^{16}$ Political reciprocity becomes coextensive with moral reciprocity. Paradoxically, then, Habermas 'resolves' the problem of immigration by dissolving it as such. For the foundation of a world state suppresses, at one stroke, the distinction between citizen and alien, inside and outside. He thereby lends credence to Kymlicka's wry

${ }^{11}$ J. Habermas, 'Struggles for Recognition in the Democratic State' in J. Habermas, The Inclusion of the Other (Cambridge, Mass.: The MIT Press, 1998) 203, 230 and 232.

12 n 10 above, 511.

13 ibid, 496.

14 J. Habermas, 'Kant's Idea of Perpetual Peace: At Two Hundred Years' Historical Remove' in n 11 above 165, 190.

${ }^{15}$ Habermas explicitly endorses the idea of a 'state of all nations' (Völkerstaat) or a 'world federal state' (Weltbundesstaat), as opposed to Kant's more modest 'federation of nations' (Völkerbund). See n 14 above, 168 and 181.

16 ibid, 199 . 
comment that 'territorial boundaries are the source of embarrassment for liberals of all stripes ...'17 Indeed, Habermas deals with political boundaries by excising them from a theory of distributive justice. On the face of it, justice can only be world justice. The inversion is complete: to Walzer's bounded justice Habermas opposes a justice that is boundless.

So, on closer consideration, neither Walzer nor Habermas get around to addressing the following question: why does immigration pose a fundamental political problem for a theory of distributive justice? To the extent that Walzer takes for granted the closure that gives rise to political community, only the moral limitations to an alleged right to closure, not the claimed right itself, are at issue in a theory of distributive justice. Habermas, for his part, can only rescue distributive justice by rendering political reciprocity coextensive with moral reciprocity, thereby ridding political community of closure-and immigration. Both approaches trivialize immigration, concealing why it is a political problem that goes to the heart of distributive justice.

In the face of this impasse, it seems natural to adopt an 'intermediate' position, which attempts to reconcile the boundedness of political community with the universality of moral obligations to strangers. In one way or another, such positions call for a moral supplement to politics. ${ }^{18}$ Although attractive at first glance, this move does not resolve the theoretical and practical problem that has emerged from the debate between Walzer and Habermas. If, on the one hand, immigration is to be dealt with as an issue of distributive justice, then it must be viewed as a politico-legal problem; but recognizing it as such presupposes a fundamental asymmetry between citizens and aliens that is irreducible to the symmetrical relations between moral individuals. Yet, on the other, simply accepting political asymmetry seems to collapse distributive justice into the sheer positivity of positive law.

\section{IV}

A fresh start is required. Indeed, a fundamental shortcoming of the ongoing debate on immigration and distributive justice is the astounding lack of interest in an explicit and sustained inquiry into how legal space is structured, and how, if at all, boundaries might constitute that space. By and large, it is simply taken for

\footnotetext{
${ }^{17}$ W. Kymlicka, 'Territorial Boundaries: A Liberal Egalitarian Perspective' in Boundaries and Justice: Diverse Ethical Perspectives, ed. D. Miller \& S. H. Hashmi (Princeton: Princeton University Press, 2001) 249. Another author indirectly voices this discomfort by claiming that all theories that are 'distributive, egalitarian, and universalistic' by temperament, including his own, 'have to conceive justice as global.' See S. Gosepath, 'The Global Scope of Justice' in Global Justice, ed. T. W. Pogge (Oxford: Blackwell, 2001) $145,154$.

18 Recent examples include S. Benhabib's The Rights of Others (Cambridge: Cambridge University Press, 2004) and Another Cosmopolitanism (Oxford: Oxford University Press, 2006), as well as n 1 above, which attempts to reconcile what he calls (political) 'particularism' and (moral) 'universalism.'
} 
granted that boundaries separate a domestic space from foreign countries. An inquiry into the structure of legal space is all the more urgent because Habermas' claim that distributive justice is boundless is polemically oriented against a second form of the inside/outside distinction that he views as constitutive for nationalism: the contrast between own and strange places. His distinction between an ethnos and a demos aims to liberate democratic self-legislation from 'the negative demarcation of the strange (Fremde) over against the own (Eigene). ${ }^{19}$ By uncoupling the inside/outside distinction from the ethnically and culturally motivated distinction between the own and the strange, what remains-the distinction between domestic and foreign spaces-is the merely contingent spatial organization of the nation-state, which can be superseded by the foundation of a world state.

To assess this thesis, we do well to accept Habermas' invitation to disencumber ourselves of a culturally loaded conception of the inside/outside distinction, and to reflect upon the most general conditions under which a world state could organize itself as a legal space. Our point of departure is that a legal space is a space of action, in contrast to, say, the space of perception. The law orders individual action by way of boundaries that establish where human behavior ought or ought not to occur. A legal space is, minimally, a distribution of ought-places, places to which individuals relate in the forms of legal emplacement or misplacement. Importantly, a legal space manifests itself as a unity of places-a 'territory.' Not only does every ought-place in a legal space include a reference to the totality of places in which it belongs, but it also draws its meaning as an oughtplace from this encompassing unity of places. This entails that boundaries join by separating. Paradoxically, boundaries only succeed in separating places, normatively speaking, if they join these places in an encompassing whole. For example, acts that qualify a boundary crossing as illegal seek to reassert the separating function of boundaries; but, to do so, they claim that the apposite individual ought to be elsewhere, thereby joining both ought-places into a spatial unity.

How can a manifold of ought-places appear as a unity? Two conditions must be met: the first is that a territory be deemed a common space; the second, that a collective lay claim to a territory as its own. The first condition concerns the binding character of boundaries: what makes a place an ought-place-the place where one ought or ought not to be-is the claim that legal boundaries give spatial expression to the common interest. The second condition is, as noted, that a collective lays claim to a territory as its own. Crucially, the reference to 'ownership' is not juridical, as in the classical legal categories of imperium or dominium. Instead, it concerns political reflexivity, in a twofold sense of the term. For the one, individuals view themselves as a unity in action that posits boundaries. For the other,

${ }^{19} \mathrm{~J}$. Habermas, 'The European Nation-State: On the Past and Future of Sovereignty and Citizenship' in $n$ 11 above, 110 (trans. altered). 
members of a collective view themselves as the individuals that have a privileged interest in the boundaries, as posited. ${ }^{20}$

So, the first term of the contrast between 'own' and 'strange' places is indispensable if we are at all to understand why legal space is a unity of oughtplaces. But need this imply that a legal space can only be structured as a unity by dint of a closure that contrasts the community's own space to strange places? Would not a world state preclude that possibility, to the extent that it inaugurates an all-inclusive political 'we'?

The snag is that a world state would have to determine, at its foundation, what interests unite its members in political reciprocity, by including some interests and (implicitly) excluding others as irrelevant. This inclusion and exclusion of interests would be reflected in the boundaries that determine where behavior ought and ought not to occur. Crucially, the founding inclusion and exclusion of interests is not the outcome of a discursive process, in the Habermasian sense of the term. Someone must seize the initiative to establish what counts as the common interest of the polity. Moreover, whoever seizes the initiative claims to act in the name of the whole, but cannot have been mandated to this effect by interested parties, because only the initiative makes it possible to establish what counts as being an interested party. Political reciprocity in a world state would depend, as in any other polity, on a non-reciprocal act to get it going. ${ }^{21}$ Certainly, there would be room for renegotiating boundaries. But instituting political equality in a world state opens up the possibility of instituting political inequality, such that world citizenship could ultimately be withdrawn from individuals who radically contest how the polity draws the boundaries defining legal emplacement and misplacement. Habermas omits mentioning in this context that securing the legal status of human rights in a world state-including a world democracy - involves introducing restrictions to their validity, the most prominent of which is the public order exception. Thus he correctly holds that 'state citizenship and world citizenship form a continuum. ${ }^{22}$ But the reason for this is that both forms of citizenship illustrate the asymmetry, explicit or implicit, that is constitutive for political reciprocity.

By the same token, although a world state would have no outside in the sense of foreign places, or at least not initially, the inclusion and exclusion of interests reflected in its boundaries entail that its foundation gives rise, at least latently, to

20 The term 'reflexivity' is, of course, highly polysemic in the philosophical literature. I draw here on the specific sense of political reflexivity outlined in B. van Roermund's powerful article, 'First-Person Plural Legislature: Political Reflexivity and Representation' (2003) 6 Philosophical Explorations 235, and to which I return in the following section.

${ }^{21}$ This, precisely, is the irresolvable problem confronting all variants of social contract theory: the prior question concerning who is to be a party to the social contract and what interest is to be the object of a contract cannot themselves be addressed by a social contract. As Waldenfels puts it, 'entry into a dialogue and exit therefrom cannot themselves be understood as dialogical without one's falling prey to a petitio principi.' B. Waldenfels, 'Vorwort: Indirekte Rede' in his Vielstimmigkeit der Rede (Frankfurt: Suhrkamp, 1999), 14. See also, earlier, B. van Roermund, Law, Narrative and Reality: An Essay in Intercepting Politics (Dordrecht: Kluwer Academic Publishers, 1997) $150 \mathrm{ff}$.

22 n 10 above, 515 . 
strange places-places that have no place within the unity of places that constitute its territory. Strange places appear abruptly, in the form of displaced behavior, behavior that dis-locates boundaries by contesting the manner in which a legal order organizes the distinction between emplacement and misplacement. A good example of boundary crossings that reveal an outside in the strong sense of strange places is provided by the Brazilian movimento sem terra-the movement of the landless. By occupying latifundia, the dispossessed do more than trespass the boundaries of rural estates; they also challenge the terms in which Brazilian law draws the distinction between legal emplacement and misplacement. Hence not only do boundaries join by separating, as noted earlier, but, conversely, boundaries also separate by joining. The boundaries that join a manifold of legal places into a unity are also the boundaries that separate this spatial unity from strange places. Although Habermas is right to note that the domestic/foreign distinction is a contingent feature of political community, what a world state could not avoid, if it is to constitute itself as a legal space, is to posit boundaries that close it off as an inside over against an indeterminate outside, an outside that becomes strange when boundary crossings that contest the claim to commonality of a legal space also intimate a different spatial ordering of human behavior-another world. Accordingly, the distinction between 'own' and 'strange' places is not primarily ethnic or culturally motivated, as Habermas thinks. This does not amount to making a pitch for local polities and against a global state, as Walzer does; my point is rather that a global polity would itself be local. In this sense, then, Habermas rightly asserts that the foundation of a world state renders possible a 'world internal politics' (Weltinnenpolitik).23 The inevitability of an outside should temper enthusiasm about the vision of boundless distributive justice: the price that must be paid for abolishing immigration through the foundation of a world state is the abrogation of a right to emigration.

Granting that legal space requires a closure, need we conclude that distributive justice does, too? The key to this question, I will now argue, is collective identity. Indeed, a systematic account of the relation between boundaries and distributive justice turns on how one interprets the 'self' of collective self-legislation. Recent studies in collective intentionality cast this issue in a way that differs substantially from both Walzer and Habermas. These studies give the lie to theories of social action that view the self of collective self-legislation as a summation of individual acts, while at the same time steering clear of an ontology that postulates that collectives exist independently of individuals and their acts. As Michael Bratman puts it, 'shared intentions are intentions of the group. But... they consist in a public,

${ }^{23}$ n 14 above, 187-188 (trans. altered). 
interlocking web of the intentions of the individuals. ${ }^{24}$ Bratman is concerned to clarify the kind of unity implied in the idea of an 'interlocking web of intentions.' His central claim is that 'shared intentional activity' turns on mutual responsiveness: reciprocity of intentions, to the extent that my intention to act is co-determined by your intention to act and vice versa, and that we know this of each other; reciprocity in the meshing of our individual plans and action, in view of bringing about the shared activity. Importantly, he carefully distinguishes shared intentional activity from shared cooperative activity: whereas the latter rules out coercion in the attainment of the collective purpose or interest, the former, of which law is an instance, does not.

Although he does not distinguish them as such, Bratman's analysis reveals that shared intentional activity deploys two forms of identity. First, the purpose or interest defining what the group is doing, and what it is about, enables a collective to identify itself as the same over time, or as becoming different, to the extent that, along the way, its members confirm or readjust their understanding of what they are doing. Paul Ricœur calls this idem-identity, identity as sameness. ${ }^{25}$ The second mode of identity is linked to the indexical 'we,' by which individuals refer to themselves as acting together. Ricœur dubs this ipse-identity, the identity of selfhood. Indeed, the word 'self' is reflexive, for it denotes agents who can refer to themselves by using first-person indexicals such as 'we,' 'us,' and 'our.'26 Importantly, collective self-legislation is reflexive insofar as individuals view themselves as members of the group that both intends to act and has an interest in the act. Following Van Roermund, I will speak here of political reflexivity. ${ }^{27}$ Ipseity implies a form of identity because, as Ricœur notes, selfhood involves a 'permanence in time.'28 Whereas he views character as the privileged manifestation of idem-identity, he sees the making and keeping of promises as emblematic for ipse-identity. I will return at the end of this paper to the problem of promises and ipse-identity, when considering the temporal structure of boundaries.

When described in this way, the first-person plural perspective is the backbone of acts of distributive justice: acts that mete out to each their own are acts by which the members of a polity are deemed (1) to articulate a common interest, and to refer to themselves as the individuals that (2), acting jointly, ascribe rights and obligations, and that (3) have a joint interest in the acts settling what rights and obligations accrue to whom. Although Walzer does not distinguish

${ }^{24}$ M. Bratman, 'I Intend That We $J$ in M. Bratman, Faces of Intention (Cambridge: Cambridge University Press, 1999) 143. Similarly, Philip Pettit indicates that 'as there is a personal perspective that is available only with talk of ' $\mathrm{I}$ ', so there is a personal perspective that becomes available only with talk of "we".' See P. Pettit, A Theory of Freedom (Cambridge: Polity, 2001) 117. Both authors refer extensively to the burgeoning literature on the subject, which includes work by Margaret Gilbert, Raimo Tuomela, and John Searle.

25 P. Ricœur, Oneself as another, (Chicago: Chicago University Press, trans. Kathleen Blamley, 1992) 1-3, 115-125.

26 P. Pettit, n 24 above, 116.

27 See $n 20$ above.

${ }^{28}$ n 25 above, 2, 118. 
these two modes of identity, and tends to collapse collective selfhood into sameness, he correctly asserts that 'the idea of distributive justice presupposes ... a group of people committed to dividing, exchanging, and sharing social goods, first among themselves' (emphasis added). For whoever cries out 'this is just!' or 'that is unjust!' already evokes the reflexive stance of a 'we' in distributive action.

Consider, now, Ulpian's famous formulation of the principle of justice-suum cuique tribuere, to each his own. As it stands, the principle is silent about space and legal boundaries. But the spatiality of distributive justice comes into view if one reinscribes justice in what the legal doctrine calls the 'spheres of validity' of legal norms. ${ }^{29}$ The basic doctrinal intuition is that as the legal 'ought' refers to human behavior, legal norms order behavior in its subjective, objective, temporal, and spatial dimensions. These spheres of validity are the most general features defining the law as a normative order. Indeed, no legal order is conceivable that does not offer responses to four different questions: Who ought to behave in a certain way? What behavior ought to come about? When ought behavior to come about? Where ought behavior to come about? Returning to the principle of justice, sum cuique tribuere evokes the material and personal scopes of legal validity, indicating who is entitled to what. Although space and time are passed over in silence, this does not mean, however, that they are only 'preconditions' of distributive justice, as though distributive acts merely come about 'in' space and time.

Turning to the latter, notice that the time of the law is first and foremost a subject-relative form of temporality, namely the historical time of a collective. As legal norms are posited from the first-person plural perspective, they situate human behavior in the temporal arc spanning the past, present, and future of a collective. These modes of time, as Émile Benveniste, the great French linguist, has noted, are irreducible to dated time. ${ }^{30}$ The unity of calendar time manifests itself as the continuum of a before and an after; by contrast, past, present, and future can only appear as a unity to the extent that they are the temporal modes of a 'we' (or an 'I'). Moreover, this self-attribution is linked to the commonality of historical time, in the twofold sense of a time that is shared by and distinguishes the members of a collective. The time of law is a limited time. Time can only manifest itself as an ought-time, the time in which behavior ought to take place, to the extent that it is deemed the common time of a collective.

Space, for its part, is a sphere of validity because law reveals space normatively, as the unity of a manifold of ought-places. And, as we have learned, the unity of a manifold of ought-places depends on two conditions. The first is that a space be deemed common, i.e. that its boundaries give spatial form to the public interest. The second is that a collective claim a space as its own, which

${ }^{29}$ H. Kelsen, Pure Theory of Law (Berkeley: University of California Press, trans. Max Knight, 1970) 12-15; H. Kelsen, Introduction to Problems of Legal Theory (Oxford: Clarendon Press, trans. Stanley L. Paulson and Bonnie Litschewski Paulson, 1992) 12-13.

30 'As a day is identical to another day, nothing says about this or that calendar day, taken in itself, whether it is past, present, or future. It cannot be placed under one of these three categories other than by who lives time.' See É. Benveniste, 'Le langage et l'expérience humaine' in Problèmes du langage, ed. É. Benveniste et al. (Paris: Gallimard, 1966) 8. 
presupposes the first-person plural perspective of a 'we' that constitutes itself as a legal space by closing off an inside over against an outside. The distributive question-where ought behavior to take place?-ultimately concerns how the boundary between inside and outside should be drawn. And this amounts to a query concerning the commonality of the territory a polity calls its own. The where-question can only be raised and answered against the horizon of a unity of ought-places, and as a renewed question about what constitutes a manifold of places as a spatial unity.

Accordingly, the four questions noted above are questions confronting a collective: they arise and are addressed from the first-person plural perspective of a 'we.' This is another way of saying that what holds together the four spheres of validity as the aspects of a single legal order is their subject-relatedness. Spatiotemporally speaking, this means that legal space cannot be organized according to the master distinction between inside and outside unless legal time is structured as a past, a present, and a future. Conversely, legal time cannot appear as the past, present, and future of a collective unless space is structured as an inside and an outside. Here, then, is the reason for which acts of distributive justice are bounded: because such acts invoke the first-person plural perspective of a 'we,' they cannot allot to each their own without also apportioning to each their own ... place and time.

This insight also explains the link between immigration and distributive justice. The administrative or judicial act that determines whether an immigrant may enter a polity renders explicit what remains implicit and taken for granted in most acts of distributive justice: sum cuique tribuere is also always suum cuique locum. And as the question about the boundary between inside and outside calls forth the question about the sense of a collective past, present, and future, such administrative or judicial acts also distribute time, indicating what entries by immigrants can be accommodated in the temporal unity of a collective: suum cuique tempus.

Let me quickly take stock. An initial survey suggested that authors as different as Walzer and Habermas encounter considerable conceptual difficulties in acknowledging that immigration poses a fundamentally political problem for a theory of distributive justice. Focusing on Habermas, the foregoing section shows why his move to render political reciprocity coextensive with moral reciprocity belies that distributive justice is bounded. My argument is, in a nutshell, that justice is spatially circumscribed because it is a reflexive process in the first-person plural perspective: every distributive act (1) posits, explicitly or implicitly, a boundary separating inside from outside, and (2) does so from within what is deemed to be a collective's own space. To this extent, Walzer's claim that 'no one on the outside 
has a right to be inside' is plausible. Indeed, there can be no law nor politics, and $a$ fortiori no distributive justice, without a prior closure. Yet, while it grants a certain plausibility to this claim, the argument sketched out heretofore also paves the way for a strong conceptual critique thereof.

To see why, we need to resume the debate with Walzer where it had been interrupted. While he correctly argues that membership is the primordial distributive issue, his discussion thereof begins too late: the spatial closure that founds a community, separating inside from outside and distinguishing citizen from alien, has already taken place. What is fascinating, however, is that Walzer's 'omission' cannot be corrected by bringing the foundational closure into the purview of a theory that lays out the criteria by which a distributive act can be qualified as just or unjust. We obliquely stumbled upon the reasons for this impossibility when considering Habermas' world state: the founding closure of a polity is not and cannot be the expression of political reflexivity because closure conditions the possibility of political reflexivity.

The foundation of the European (Economic) Community offers a good illustration of this quandary. The Preamble to the Treaty of Rome, enacted in 1957, states that the parties to the Treaty are 'determined to lay the foundations of an ever closer union among the peoples of Europe.' Notice, to begin with, that the enactment of the Treaty is a distributive act in the fourfold sense of the foregoing section: it indicates who is a party to the collective, what are their common interests, where this interest is located, and when this interest comes about, namely, in the course of a European history that has already commenced and which is to be safeguarded and intensified in the future through the foundation, now, of the European polity. Moreover, while the six founding Member States claimed to represent Europe as a spatial unity, they had received no legal mandate to this effect from all relevant parties, nor could they have: the founding act determines who is a relevant party by indicating where their interest is located-in a common market. Importantly, the European polity and its Member States not only expect individuals inside but also those outside to recognize and abide by the (incipient) right to closure claimed for the EC in the immigration policy provisions of the Amsterdam Treaty of 1997. Yet the preferential distinction between European and non-European, arises through a closure that cannot be the outcome of a joint act by these two groups, because it gives rise to them in the first place. As a result, European immigration policy rests on a circularity that resists resolution: the European polity claims a right to include and exclude aliens because Europe is the own place of its citizens; yet, to begin with, an act of inclusion and exclusion gives rise to European citizens and their own place. ${ }^{31}$

31 I develop this issue at greater length in 'Finding a Place for Freedom, Security and Justice: The European Union's Claim to Territorial Unity' (2004) 29 European Law Review 461. Benhabib makes a similar point in The Rights of Others, $\mathrm{n} 18$ above, 20 ff, and in Another Cosmopolitanism, n 18 above, 17-20. Although I cannot discuss this issue in this paper, I submit that Benhabib's development of the normative implications of this paradox underestimates the intertwinement of law and violence to which it 
This circularity, which is constitutive for every imaginable polity, disrupts the simple oppositions between inside and outside, and right and fact, which underpin Walzer's defense of a right to closure. Turning, first, to the opposition between inside and outside, consider, once again, the Preamble to the Treaty of Rome: ' . . . determined to lay the foundations of an ever closer union among the peoples of Europe.' Notice that the Treaty does not only distribute space by separating and opposing an inside (Europe) and an outside (the rest of the world). In the same movement by which the Treaty closes off the European polity from the rest of the world, it includes the EC and what is excluded therefrom in an encompassing spatial unity: a world market, the denizens of which are viewed as economic actors subject to the rules of market exchange. The logic of boundaries is at work here: boundaries separate by joining. Importantly, the second leg of the logic of boundaries is also at work: the Treaty distributes space by separating Europe from itself: it splits Europe, including it as a common market and excluding other possible interpretations of what constitutes it as a common space, such that contestation of the common market can erupt in the name of 'another Europe.' The closure that gives rise to the common market cannot represent Europe as the common space of a community without folding a strange Europe into what is claimed to be the EC's own place. Whence the logic of boundaries: boundaries join the EC's member states into a common market by separating the latter from another Europe. Moreover, the Treaty also distributes space by separating the world from itself. In the same movement by which the Treaty splits Europe, it also splits the world, representing it as a market. The cry, 'Another world is possible,' uttered in places such as Porto Alegre, reveals that the EC cannot take its place in a world market without folding a strange world into the world it calls its own. The logic of boundaries kicks in yet a third time: the boundaries of the internal market join it to the external market by separating the world market from other worlds.

Accordingly, the circularity governing the founding distributive act distuptswithout effacing - the opposition between inside and outside. Indeed, it ensures that a legal space is never entirely a community's own place, and this for two reasons. For the one, every community harbors strange places within what it calls its own legal space: distributive acts deploy an inclusive exclusiveness. For the other, the collective's own place can appear as elsewhere than in the legal space that claims to give it institutional form: distributive acts deploy an exclusive inclusiveness. Contrary to Walzer's (and Habermas') assumption, the distributive act that closes a community never simply divides and opposes an inside and an outside: the founding closure brings in what it pushes out—and pushes out what it brings in. The logic of boundaries, according to which boundaries cannot separate without joining, nor join without separating, is the obverse of the logic of distributive acts, which cannot exclude without including, nor include without excluding.

gives rise. For a discussion of this intertwinement in the context of Schmitt's thesis that political community arises through a 'taking,' see my article, 'Give and take: Arendt and the nomos of political community’ (2006) 32 Philosophy and Social Criticism 881. 
The disruption of the pat opposition between inside and outside is paired to a disruption of the simple opposition between right and fact. The circularity of the founding closure reveals an ineluctable de facto core in the alleged jus includendi et excludendi polities claim for themselves. This is particularly clear with respect to the de facto immigrant, that is, the economic immigrant who seeks entry by applying for the status of political asylum seeker. As a reputed scholar puts it, "[a]lthough the EU Member States have unanimously denied that they are countries of immigration, by and large all have eventually become de facto immigration countries. The flow of asylum applicants has become a major source of de facto immigration. 32 While he defends the 'legitimate right' of the EU and its Member States to curb such immigration, the aforementioned circularity disrupts the clean split between right and fact to which he appeals. Indeed, by including Europe and the rest of the world in an encompassing whole, the Treaty of Rome already posits a minimal reciprocity between European citizens and aliens: 'we,' participants and interested parties in a world market. Boundary crossings by de facto immigrations point to a threshold of distributive justice that I will call 'proto-political reflexivity.' I speak of proto-political reflexivity, rather than of moral reflexivity, because economic migrants seize the initiative to implicitly evoke the first-person plural perspective of a 'we' that has a shared interest in the realization of a world market. ${ }^{33}$ But I speak of proto-political reflexivity, instead of political reflexivity tout court, because the first-person plural perspective enjoined by the process of realizing a world market has not obtained institutional form by way of officials that, acting on behalf of a 'we,' can authoritatively arbitrate about claims raised by economic migrants. To put it in Bratman's terms, such claims are not yet settled within the framework of an institutionalized process of shared intentional activity. It would not be inconsistent with the EC's commitment to the realization of a world market that it agree to the enactment of a body in the World Trade Organization that could authoritatively settle such claims. In any case, de facto immigrants entering the EC raise an embryonic de jure claim as interested parties to the world market. Notice the inverted symmetry, which disrupts Walzer's pat opposition between right and fact: in the same way that there is a de facto core to a polity's de jure claim concerning its boundaries, boundary crossings by de facto immigrants also intimate a de jure claim to another way of apportioning to each their own place.

Crucially, the commonality a polity claims for its boundaries already includes a reference to the world in which the polity, together with other polities, claims a

32 K. Hailbronner, 'Asylum Law in the Context of a European Migration Policy' in Europe's Area of Freedom, Security and Justice, ed. N. Walker (Oxford: Oxford University Press, 2004) 41, 42.

33 As politics is indissolubly linked to the first-person plural perspective of a 'we,' what precedes the institutionalization of this perspective is not the first-person singular perspective of morality but variations of proto-political reflexivity that shade out into more or less inchoate manifestations of a joint interest. Arendt's celebrated formula, the 'right to have rights,' does not mean a 'moral' right to have 'legal' rights; it is, I submit, a felicitous articulation of the threshold leading from proto-political to political reflexivity. See H. Arendt, The Origins of Totalitarianism (New York: Harcourt, Brace and Company, 1973 [1951]) 296. 
place for itself: in the same movement by which a founding closure separates inside from outside, preferring the former to the latter, it includes both places within a more encompassing spatial unity (e.g. the world market), which is itself preferred to an indeterminate outside. The act of a collective subject that separates inside from outside eo ipse posits the world as intersubjectively constituted. In this way, the subject-relatedness of a legal world is not merely the expression of subjectivity, in the sense of arbitrariness, but also involves the claim to a standard of objectivity or justice of which a collective is not the sole custodian. Here, then, is the reason why immigration poses a political problem for a theory of distributive justice: Although distributive acts take place from the first-person person plural perspective of a spatially bounded 'we,' acts that decide on the legality or illegality of boundary crossings by immigrants can only claim to being just to the extent that they posit the preferential distinction between inside and outside in a way that safeguards the commonality of the world in which the polity claims to take its place.

\section{VII}

How, then, is distributive justice possible when immigration contests the commonality of the boundaries of the polity and of the world in which it takes up its place? Rather than trying to undo, downplay, or belie the circularity that founds a community's self-closure, we must resolutely embrace it, transforming it into the touchstone of an alternative theory of the relation between immigration and distributive justice. This requires that we introduce a problem I have kept in reserve hitherto: time. Although it was asserted that sum cuique locum is paired to suum cuique tempus, a more precise formulation of this coupling is required. In effect, the aforementioned circularity attests to what might be called the 'paradox of representation': an act can only originate a community by representing its origin. To found a community, an act must re-found it, which means that the community is never directly present to itself; it must always be represented. This paradox holds, on the one hand, for the first-person plural perspective: there is no 'we' in the absence of an act that seizes the political initiative to say who belongs to a collective and what goal or interest joins them together; but this act only succeeds in creating a community if 'we' retroactively identify ourselves as the individuals that had founded a political community. It holds, on the other, for legal space: an act can only inaugurate a community, closing it into a legal space, by representing a prior closure to which it has no direct access. ${ }^{34}$

This paradox ruins the simple opposition between an inaugural closure and subsequent acts that enforce the boundaries of a polity. If the founding closure

${ }^{34}$ I explore the ontological implications of the paradox of representation in 'Constituent Power and Reflexive Identity: Towards an Ontology of Collective Selfhood' in The Paradox of Constitutionalism, eds. M. Loughlin and N. Walker (Oxford: Oxford University Press, 2007) 9. 
claims to enforce and maintain boundaries that had been drawn earlier, acts that enforce and maintain boundaries always found anew the spatial unity of a polity and of the world in which a polity takes up its place-even when confirming extant boundaries. If the paradox of representation requires that distributive acts justify the qualification of a boundary crossing as legal or illegal by deriving that qualification from a prior closure, it also requires of these acts that they decide what counts as legal or illegal immigration, retroactively determining how the boundaries separating inside from outside had joined both the polity and what was excluded therefrom into an encompassing world. In response to an embryonic de jure claim by de facto immigrants, a distributive act can seize the initiative to redefine the boundaries of the collective, such that this de facto act retrospectively can be viewed as having been de jure. To be sure, the interaction between boundary crossings and the acts that qualify them is irreducible to the automatism of, say, 'stimulus and response.' An integral part of establishing what counts as a legal or illegal boundary crossing is determining which crossings trespass boundaries and which transgress them by calling into question the distinction between inside and outside. Immigration policy is responsive in a strong sense of the term, for 'that to which it responds occurs only in responding to it.'35

I would add that the responsiveness of immigration policy involves a political judgment about past and future that takes issue in a decisive aspect with Ricœur's discussion of collective identity. I mentioned in Section $\mathrm{V}$ that, according to Ricœur, the first person perspective involves two forms of identity. Idem-identity, as illustrated by 'character,' concerns what remains the same over time. While ipseidentity also denotes a form of permanence in time, the example of promises makes clear that self-identity is irreducible to what remains the same over time. In effect, 'keeping one's promise ... appear[s] to stand as a challenge to time, a denial of change: even if my desire were to change, even if I were to change my opinion or my inclination, "I will hold firm". 36 Although Ricœur develops this idea with respect to personal identity, it also holds for the identity of a collective self. Indeed, Hannah Arendt, whose writings Ricœur no doubt had in mind, notes that "the power generated when people gather together and "act in concert" ... is the force of mutual promise...' And she adds that the mutual promise between the members of a polity has the power to stabilize time, not because those who promise share 'an identical will which somehow magically inspires them all,' but by virtue of 'an agreed purpose for which alone the promises are valid and binding. ${ }^{37}$ On this reading, boundaries are binding over time to the extent that political selfclosure is the expression of a mutual promise.

${ }^{35}$ B. Waldenfels, Antwortregister (Frankfurt: Suhrkamp, 1994) 266.

${ }^{36} \mathrm{n} 25$ above, 124.

37 Hannah Arendt, The Human Condition (Chicago: Chicago University Press, 1958) 244-245. Identity, defined as the permanence of a collective self in time, figures discretely in Bratman's references to the 'commitment to the joint activity,' and prominently in Pettit's discussion of the consistency or coherence of collective judgments over time. See R. Bratman n 24 above, 95, and P. Pettit n 24 above, $111 \mathrm{ff}$. 
This insight, although crucial, must be amended. For the linear temporality suggested by the notion of a promise that is first made and then kept is belied by the paradoxical temporality of political judgment. For the task of political judgment is to anticipate the meaning of the past in the future: immigration policy has to decide what promises had been made in the light of boundary crossings that determine what promises can be kept. As such, political judgment dislocates the simple progression of a temporal arc that begins in the past and that, passing through the present, leads into the future. To be sure, the fact that political judgment anticipates the past in the future does not mean that the past is simply at its disposition. For the past would cease to be such if it were under the control of acts that redefine its meaning as they see fit. By the same token, promises would cease to be promises unless they could be kept or broken. I submit that the political judgment deployed in immigration policy has the structure of a wager: it involves a reasoned initiative concerning the commonality of boundaries in the face of a past and a future that elude the collective's control.

Accordingly, the spatiality of distributive justice is rooted in time, in the paradoxical temporality of representation. On the one hand, there could be no distributive justice unless the exercise of political judgment in immigration policy were able to breach the promise that had been made, by founding anew the distinction between inside and outside in response to boundary crossings that challenge the place a collective claims for itself in a larger world. This breach is $a$ topic, by dint of being neither inside nor outside the collective, and a-chronic because it interrupts the temporal arc spanning the past, present, and future of a collective. Not a 'dialectic of self and the other than self,'38 but rather a moment of nonidentity - a suspension of collective selfhood as holding firm in time-is a necessary condition for distributive justice. On the other, there could be no distributive justice unless the breach can be viewed retrospectively as having kept the promise made at the foundation of a polity, as the renewal of a closure that not only separated inside from outside but also assured the community of its own place within the world it deemed common.

\section{VIII}

It is becoming increasingly clear what happens when political judgment does not break promises to keep them. For if the de facto immigrant attests to a first threshold of distributive justice, which I called 'proto-political reflexivity,' s/he now also embodies a second threshold thereof, which might be dubbed 'postreflexive politics.' The conditions under which asylum seekers are held at Italy's Lampedusa Airport Zone CPTA illustrate what this concretely means. According to the Italian government, CPTA's (Centri di Permanenza Temporanea e Assistenza) are

38 n 25 above, 3 . 
the instrument selected to enable the provisions for the repatriation of aliens who have entered Italy illegally to be carried out more effectively ... they are also one of the key means of ensuring the effective functioning of expulsion procedures which ... is a pre-condition for the correct implementation of an immigration policy based on annual quotas. ${ }^{39}$

Not Amnesty International's reports of allegations of 'physical assault by law enforcement officers' and other personnel of the centers, not the 'excessive and abusive administration of sedative and tranquilizing drugs,' not the 'unhygienic living conditions,' not the 'unsatisfactory medical care,' and the like are most fundamentally at stake in Lampedusa, however horrific all of this may be. What is essential from the perspective of political reflexivity is the status of the immigrants who 'stay' at the Center, such that expulsion can be a pre-condition for immigration policy. In this respect, Amnesty International has expressed serious reservations about the detention of immigrants in CPTA's, arguing that such detention is disproportionate in the face of international standards. The Italian government has countered this critique by saying that immigrants are 'held' (trattenuti), rather than detained, at the Lampedusa CPTA. The distinction is crucial, albeit in a way different to that intended by the Italian government. To qualify an immigrant as a detainee is to recognize that $\mathrm{s} / \mathrm{he}$ is misplaced, thus that, although illegally, s/he has entered a legal space. Entry to the European legal space is precisely what the holding center at Lampedusa is designed to avoid. Indeed, Lampedusa confronts the EC with the following paradox: the founding selfclosure calls forth the possibility, held in suspense until the circumstances so require, of enforcing the borders of the polity by dis-owning part of Europe. This 'dis-owning' amounts to a suspension of political reflexivity as a condition for sustaining the first-person plural perspective of a 'we' as a bounded political community. This twofold movement is what makes of a land dis-owning a form of 'post-reflexive politics.' ${ }^{\prime} 0$

That distributive justice is spatially bounded means that it poses two thresholds for immigration policy. The first marks the point prior to which an immigrant is deemed to have a stake in the political 'we,' hence a person who has, in one way or another, a de jure interest in the distribution of rights and goods by the community. This is the threshold at which the distinction between the just and the unjust begins to take hold-proto-political reflexivity. The second threshold marks the point beyond which claims by immigrants cease to register as claims

39 Cited in the Amnesty International Report, 'Italy. Temporary Stay - Permanent Rights: The treatment of foreign nationals detained in 'temporary stay and assistance centres' (CPTAs)' at http://web.amnesty.org/library/print/ENGEUR300042005 (last visited 30 May 2007).

${ }^{40} \mathrm{By}$ introducing this term, I am suggesting that a more complete analysis of the structure of the state of exception would need to deal with the problem of political reflexivity, an issue that obtains little or no attention in either Schmitt or Agamben. See C. Schmitt, Political Theology: Four Chapters on the Concept of Sovereignty (Cambridge, Mass.: MIT Press, trans. George Schwab, 1985 [1922]), and G. Agamben, State of Exception (Chicago: Chicago University Press, trans. Kevin Attell, 2005). 
that call for distributive acts by legal officials because they are uttered in a place that, stripped of its normative dimension, has reverted to the status of a non-place that is neither inside nor outside a polity. At this point, the distinction between the just and the unjust has been obliterated-post-reflexive politics. These non-places, in which the immigrant finally becomes a thoroughly de facto immigrant, are also the non-places in which a community ceases to claim a right to closure, such that its founding closure becomes nothing more than a de facto act—an act of violence. 